THE PROBLEM OF DISTRACTION 
This page intentionally left blank 


\section{THE PROBLEM OF DISTRACTION}

Paul North 
Stanford University Press

Stanford, California

(C) 2012 by the Board of Trustees of the Leland Stanford Junior University.

All rights reserved.

This book was published with the assistance of the

Frederick W. Hilles Publication Fund of Yale University.

No part of this book may be reproduced or transmitted in any form or by any means, electronic or mechanical, including photocopying and recording, or in any information storage or retrieval system without the prior written permission of Stanford University Press.

Library of Congress Cataloging-in-Publication Data

North, Paul, 197I- author.

The problem of distraction / Paul North. pages $\mathrm{cm}$

Includes bibliographical references and index.

ISBN 978-0-8047-7538-o (cloth : alk. paper)

ISBN 978-0-8047-8687-4 (pbk. : alk. paper)

I. Distraction (Philosophy) 2. Philosophy, Modern. I. Title.

BIo5.D58N67 201I

$128^{\prime} \cdot 3$ - dc22 
For my parents 
This page intentionally left blank 
In te, anime meus, tempora mea metior. Noli mihi obstrepere; quod est, noli tibi obstrepere turbis affectionum tuarum.

In you, O my mind, I measure my times. Do not interrupt me; that is, do not interrupt yourself with a disturbance of your affections.

-augustine, Confessions 
This page intentionally left blank 